\title{
Glucose utilization and lactate production by Helicobacter pylori
}

\author{
George L. Mendz, ${ }^{*}$ Stuart L. Hazell and Brendan P. Burns \\ Schools of Biochemistry and Molecular Genetics and Microbiology and Immunology, The University of \\ New South Wales, PO Box 1, Kensington, NSW 2033, Australia
}

(Received 12 January 1993; revised 25 June 1993; accepted 29 June 1993)

\begin{abstract}
The transport and incorporation of D-glucose into the human pathogen Helicobacter pylori was investigated employing radioactive tracer analysis and ${ }^{1} \mathrm{H}$ and ${ }^{13} \mathrm{C}$ nuclear magnetic resonance spectroscopy. The bacterium was found to utilize D-glucose contrary to the accepted view that it cannot catabolize carbohydrates. Under the experimental conditions employed, the rate of transport of $\left[{ }^{14} \mathrm{C} \mid\right.$ glucose was $3.24 \mathrm{mmol} \mathrm{min}^{-1}\left(\mathrm{~g}_{\text {protein }}\right)^{-1}$, and the rate of incorporation into the cellular mass was $1.06 \mu \mathrm{mol} \mathrm{h}{ }^{-1}$ (g protein) $)^{-1}$. The utilization of $\left[{ }^{13} \mathrm{C} / \mathrm{glucose}\right.$ showed biphasic characteristics with a slower initial period followed by a phase with a rate of utilization at least an order of magnitude faster. The apparent rates of decline of glucose levels during both phases varied between strains and depended on the growth conditions of the bacteria prior to harvesting. The main product of glucose catabolism was identified as lactate. These findings provide new perspectives into the physiology of $H$. pylori and have implications for the active search to develop appropriate therapies for the micro-organism.
\end{abstract}

\section{Introduction}

Helicobacter pylori is a Gram-negative, vibrioid, microaerophilic bacterium that has been established as the major aetiological agent of active chronic gastritis (Marshall \& Warren, 1984; Morris \& Nicholson, 1987), associated with peptic ulcers (Hornick, 1987), and more recently linked to the development of gastric cancer in humans (Parsonnet et al., 1991; Nomura et al., 1991). The overall metabolism of $H$. pylori remains poorly understood although major studies on the virulence and pathogenic effects of bacterial enzymes have been carried out (Ferrero et al., 1988; Hazell et al., 1991; Hazell, 1992). The absence of fermentative pathways for saccharides was reported at the time of the discovery of the bacterium (Marshall \& Warren, 1984) and confirmed later in different investigations (McNulty \& Dent, 1987). These studies employed standard microbiological techniques or rapid identification kits for the detection of preformed enzymes. An unwarranted extrapolation of these results led to the view that $H$. pylori cannot catabolize carbohydrates in common with other Campylobacter-like bacteria. The recent discovery in the micro-organism of the enzymes of the pentose phosphate pathway (Mendz \& Hazell, 1991) and of glucokinase

\footnotetext{
* Author for correspondence. Tel. +6126972042; fax +6123136271 .
}

activity (Mendz \& Hazell, 1993), suggested that $H$.pylori might be able to utilize glucose via this pathway. Since the sources of carbon and energy employed by the bacterium have not been identified, the investigation of glucose utilization by intact, metabolically competent cells was an important step towards characterizing the physiology of the micro-organism.

\section{Methods}

Substrates and reagents. Radiolabelled $\mathrm{D}-\left[\mathrm{U}-{ }^{14} \mathrm{C}\right] \mathrm{glucose}[320 \mathrm{mCi}$ (11.84 GBq) $\left.\mathrm{mmol}^{-1}\right]$ was from Amersham; and ${ }^{3} \mathrm{H}_{2} \mathrm{O}[100 \mathrm{mCi}$ $\left.(370 \mathrm{MBq}) \mathrm{g}^{-1}\right]$ and $\left[1,2-{ }^{14} \mathrm{C}\right]$ polyethylene glycol (PEG) $[0 \cdot 1 \mathrm{mCi}$ (3.7 MBq) $\mathrm{ml}^{-1}$ ] from New England Nuclear. D-[1- $\left.{ }^{13} \mathrm{C}\right]$ Glucose, D-[6$\left.{ }^{13} \mathrm{C}\right]$ glucose and $\mathrm{D}-\left[\mathrm{U}-{ }^{13} \mathrm{C}\right]$ glucose were obtained from Cambridge Isotope Laboratories. Blood Agar Base no. 2, Brain Heart Infusion broth and Isosensitest broth were from Oxoid, and bovine serum albumin Fraction V (BSA, A2153) and bovine liver catalase $\left(1600 \mathrm{U} \mathrm{mg}^{-1}, \mathrm{C} 6665\right)$ from Sigma. Di-n-butyl phthalate and di-isooctyl phthalate were from Ajax Chemicals. Scintillation grade 2,5diphenyloxazole (PPO) was from Packard and 1,4-bis-(4-methyl-5phenyl-2-oxazolyl)benzene (DMPOPOP) was from Sigma. All other reagents were of analytical grade. Phosphate-buffered saline (PBS) at pH 7.4 was prepared with $0.9 \% \mathrm{NaCl}$ and $5 \mathrm{~mm}$-phosphate. Scintillation fluid for measuring the radioactivity of dry solid samples was a toluene solution of $0.5 \%$ PPO and $0.03 \%$ DMPOPOP. Liquid samples were analysed employing a toluene/Triton X-100 (2:1, v/v) solution. Sterile Minisart $0 \cdot 2 \mu \mathrm{m}$ and Whatman GF/C $1.6 \mu \mathrm{m}$ glass fibre filters were purchased from Selby Scientific. Self-vented tissue culture flasks were from Becton and Dickinson. Protein content of samples was determined by the bicinchoninic acid method employing a microtitre protocol (Pierce). 
Bacterial cultivation and preparation. H. pylori strains NCTC 11639 , UNSW P10 and UNSW 921006 were grown on horse blood agar plates (Blood Agar Base no. 2, 5\% (v/v) horse blood) and incubated in a Stericult incubator in an atmosphere of air with $10 \%(\mathrm{v} / \mathrm{v}) \mathrm{CO}_{2}$ and $95 \%$ relative humidity at $37^{\circ} \mathrm{C}$ for $60 \mathrm{~h}$. Isolates $\mathrm{P} 10$ and 921006 were obtained from the University of New South Wales culture collection. Strain P10 was originally isolated from an adult attending for an endoscopic examination in relation to upper gastric pain, and strain 921006 was originally isolated from a child with gastric ulceration. Bacterial cells were harvested in sterile $\mathrm{NaCl}(0.9 \%)$ immediately prior to experiments, checked for purity by phase contrast microscopy and tested for urease and catalase activity which are highly active in $H$. pylori. Cells were centrifuged at $17000 \mathrm{~g}\left(6^{\circ} \mathrm{C}, 8 \mathrm{~min}\right)$, the supernatant was discarded and the pellet collected and resuspended in saline. Cells were washed three times. Following the final wash, packed cells were resuspended in sterile PBS for the transport experiments, inoculated into Isosensitest broth for incorporation experiments, or resuspended in Brain Heart Infusion or Isosensitest broth for utilization experiments.

Glucose transport. Suspensions of washed cells in PBS were added to the same buffer containing $\mathrm{D}-\left[\mathrm{U}-{ }^{14} \mathrm{C}\right]$ glucose layered over a mixture of n-butyl phthalate/iso-octyl phthalate $(4: 1, \mathrm{v} / \mathrm{v})$, and quickly spun to pellet the cells under the oil layer. Triplicate measurements were carried out at each time point. The net label transported into the cells was determined by subtracting the label in the extracellular space from the total label in the pellet (Gero et al., 1989). The total water space was measured using tritiated water, and the extracellular space using $\left[{ }^{14} \mathrm{C}\right]$ PEG.

Glucose incorporation. Bacterial cells harvested from horse blood agar plates were inoculated into $50 \mathrm{ml}$ of liquid Isosensitest semidefined medium supplemented with BSA $(0.5 \%)$, catalase $(0.1 \%)$ and

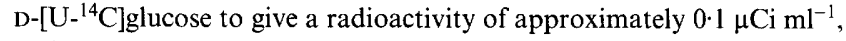
and incubated at $37{ }^{\circ} \mathrm{C}$ in an atmosphere of air with $10 \% \mathrm{CO}_{2}$, and $95 \%$ humidity. Two cultures were incubated in each experiment and duplicate $1 \mathrm{ml}$ samples from each culture were assayed at each sampling time. To remove the incubation media, cells from each sample were precipitated by centrifugation at $13845 \mathrm{~g}\left(20^{\circ} \mathrm{C}, 3 \mathrm{~min}\right)$, washed three times in PBS by the same procedure, and resuspended in $100 \mu \mathrm{l}$ PBS. The incorporation of the radioactive marker into the cellular mass was measured as previously described (Gutteridge \& Garborak, 1979). Cells were lysed and nucleic acids and proteins released by adding $1 \mathrm{ml}$ $10 \%(\mathrm{w} / \mathrm{v})$ trichloroacetic acid (TCA) to $10 \mu 1$ suspensions. Solid cell precipitates were collected on $1.6 \mu \mathrm{m}$ pore diameter glass fibre filters, washed three times in 5\% TCA and once in $1 \%$ acetic acid, placed in scintillation vials and allowed to dry. Scintillation fluid $(10 \mathrm{ml})$ was added to each vial and the radioactivity measured as disintegrations per minute (d.p.m.) in a Packard 1900TR Liquid Scintillation Analyzer.

Glucose utilization and identification of catabolic products. Following the final wash after harvesting, packed cells were resuspended to a concentration of approximately $10^{8}-10^{9}$ cells ml $^{-1}$ in Brain Heart Infusion broth containing $1 \%(\mathrm{w} / \mathrm{v})$ horse serum, or Isosensistest broth supplemented with BSA $(0.5 \%)$ and catalase $(0.1 \%)$. For NMR measurements cell suspensions were transferred to 5 or $10 \mathrm{~mm}$ tubes (Wilmad) which, after addition of labelled glucose, were plugged with cotton wool and incubated in air for up to $50 \mathrm{~h}$. Free induction decays were collected using a Bruker AM-500 or ACP-300 NMR spectrometer, operating in the pulsed Fourier transform mode with quadrature detection. Measurements were carried out at $37^{\circ} \mathrm{C}$. ${ }^{13} \mathrm{C}$ spectra were acquired with composite pulse decoupling. The instrumental parameters for the AM-500 spectrometer were: operating frequency $125.77 \mathrm{MHz}$, spectral width $10000 \mathrm{~Hz}$, memory size $16 \mathrm{~K}$, acquisition time $0.82 \mathrm{~s}$, number of transients 1200 , and pulse angle $45^{\circ}(3 \mu \mathrm{s})$. Exponential filtering of $2 \mathrm{~Hz}$ was applied prior to Fourier transformation. The instrumental parameters for the ACP-300 spectrometer for one-dimensional experiments were: operating frequency $75.5 \mathrm{MHz}$, spectral widths $8074-16129 \mathrm{~Hz}$, memory size $16 \mathrm{~K}$, acquisition times $0.508-1.016 \mathrm{~s}$, number of transients 1200 , and pulse angle $66^{\circ}(9 \mu \mathrm{s})$. Exponential filtering of $1 \mathrm{~Hz}$ was applied prior to Fourier transformation. The acquisition parameters for two-dimensional ${ }^{13} \mathrm{C}$ heteronuclear correlated (COSYX) experiments were: spectral width $13888.9 \mathrm{~Hz}, 0.0737 \mathrm{~s}$ recycling time, and 96 free-induction decays were averaged over 2048 memory locations. Contour maps of $2048 \times 2048$ data points were obtained from 1024 individual experiments by zero filling in the evolution time domain prior to Fourier transformation. The plots are absolute-value mode, with sine-bell apodization along the acquisition and evolution time domains. For two-dimensional $\left[{ }^{13} \mathrm{C}-{ }^{1} \mathrm{H}\right]$ heteronuclear shift-correlated experiments the acquisition parameters were: ${ }^{13} \mathrm{C}$ spectral width $13888.9 \mathrm{~Hz},{ }^{1} \mathrm{H}$ spectral width $2994.0 \mathrm{~Hz}$, recycling time $0.147 \mathrm{~s}$, and 88 free-induction decays were averaged over 4096 memory locations. Contour maps of $4096 \times 1024$ data points were obtained from 512 individual experiments by zero filling in the evolution time domain before Fourier transformation. The plots are absolute-value mode, with gaussian and sine-bell apodizations in the acquisition and evolution time domains, respectively. ${ }^{13} \mathrm{C}$ chemical shifts are quoted relative to carbon nuclei in position 6 at 61.7 p.p.m. (Bock \& Thørgersen, 1982). The spectral positions (chemical shifts) of resonances in one-dimensional spectra and contours in two-dimensional maps are given in parts per million (p.p.m.) units. These are normalized frequency units which allow direct comparison of NMR spectra acquired with spectrometers of different operating frequencies. The axes $\Omega_{1}$ and $\Omega_{2}$ of two-dimensional contour plots are the frequency domains corresponding to the Fourier transformation of the evolution and acquisition time domains, respectively.

One-dimensional ${ }^{1} \mathrm{H}$ NMR spectra were acquired at $500 \mathrm{MHz}$ with presaturation of the water resonance. The instrumental parameters were: spectral width of $4201.7 \mathrm{~Hz}$, memory size $16 \mathrm{~K}$, acquisition time $1.95 \mathrm{~s}$, number of transients 40 , and pulse angle $90^{\circ}(10 \mu \mathrm{s})$. Exponential filtering of $1 \mathrm{~Hz}$ was applied prior to Fourier transformation. The acquisition parameters for two-dimensional ${ }^{1} \mathrm{H}$ homonuclear correlated (COSY) experiments with presaturation of the solvent resonance were: spectral width $4201.7 \mathrm{~Hz}, 2.044 \mathrm{~s}$ recycling time, and 56 free-induction decays were averaged over 2048 memory locations. Contour maps of $2048 \times 2048$ data points were obtained from 1024 individual experiments by zero filling in the evolution time domain prior to Fourier transformation. The plots are absolute-value mode, with sine-bell apodization along the acquisition and evolution time domains. ${ }^{1} \mathrm{H}$ chemical shifts are quoted relative to 3-trimethylsily-[2,2,3,3]propionate at 0 p.p.m. COSYX and COSY maps were symmetrized employing standard Bruker programs.

\section{Results}

\section{Glucose transport and incorporation}

Under the experimental conditions employed glucose was transported into $H$. pylori cells at rates dependent on the strain employed. For strain NCTC 11639 the initial rate (with standard error) was $0.25 \pm$ $0.02 \mathrm{pmol} \mathrm{s}^{-1}(\mu \mathrm{l} \text { cell water })^{-1}$, equivalent to $3 \cdot 24 \pm$ $0.25 \mathrm{mmol} \mathrm{min}^{-1}$ (g protein) $)^{-1}$ (Fig. 1 a). In liquid culture, the incorporation of radioactive marker to the cellular mass was found to be linear for $30 \mathrm{~h}$. The rates of incorporation varied between strains. An average rate of incorporation (with standard error) of $1.06 \pm$ $0.08 \mu \mathrm{mol} \mathrm{h}^{-1}$ (g protein) $)^{-1}$ was measured for the UNSW P10 strain (Fig. $1 b$ ). 

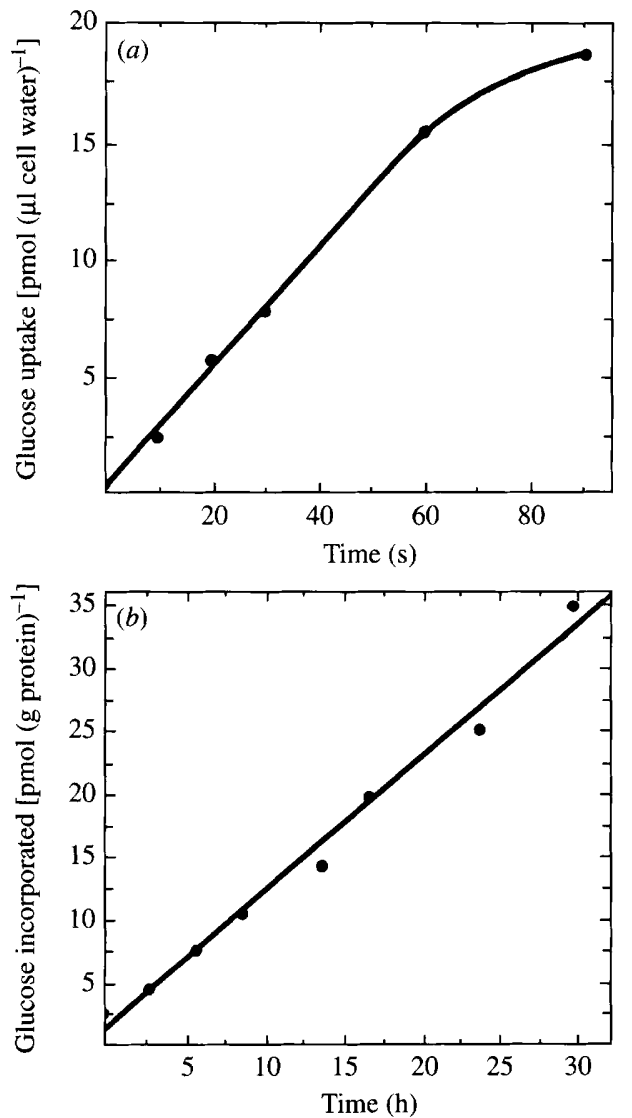

Fig. 1. (a) Transport of labelled D-[U- $\left.{ }^{14} \mathrm{C}\right]$ glucose into $H$. pylori strain NCTC 11639 cells. The initial D-glucose concentration was $2 \mu \mathrm{M}$ with $0.4 \mu \mathrm{Ci} \mathrm{m}]^{-1}$ of label. (b) Incorporation of labelled D-[U- $\left.{ }^{14} \mathrm{C}\right]$ glucose into $H$. pylori UNSW P10 cells. Cells were suspended in Isosensitest broth supplemented with $\mathrm{D}-\left[\mathrm{U}-{ }^{14} \mathrm{C}\right]$ glucose $\left(0 \cdot 1 \mu \mathrm{Ci} \mathrm{ml}^{-1}\right)$ and incubated in tissue culture flasks in an atmosphere of air with $10 \% \mathrm{CO}_{2}$ at $37^{\circ} \mathrm{C}$. The initial glucose concentration was $11.1 \mathrm{~mm}$ with $0.1 \mu \mathrm{Ci} \mathrm{ml^{-1 }}$ of label.

\section{Glucose utilization}

Incubations of bacterial cells in sterile liquid culture medium supplemented with $\mathrm{D}-\left[{ }^{13} \mathrm{C}\right] \mathrm{glucose}$ universally labelled, or with label in position 1 or 6 showed the disappearance of the glucose substrate and concomitant appearance of labelled products in the ${ }^{13} \mathrm{C}$ NMR spectra of cell suspensions (Fig. 2). The decline of $\left[{ }^{13} \mathrm{C}\right]$ glucose label showed biphasic characteristics with an initial slow period of glucose metabolism, followed by a second phase with a rate of disappearance of label at least an order of magnitude faster than the initial rate. Similar patterns of $\mathrm{D}-\left[{ }^{13} \mathrm{C}\right]$ glucose utilization were observed in all three strains tested, but the duration of the initial phase $(5-25 \mathrm{~h})$ and the rates of decline of labelled glucose during both phases varied between strains and depended on the growth conditions of the bacteria prior to harvesting (Table 1). Cells grown in glucose-supplemented plates showed faster rates of utilization of

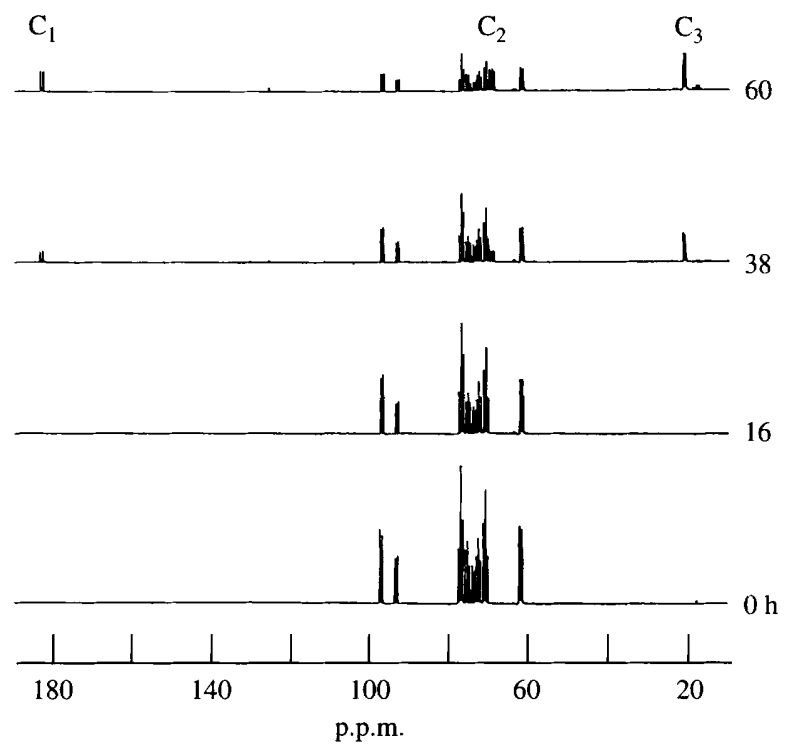

Fig. 2. Sequential ${ }^{13} \mathrm{C}$ nuclear magnetic resonance spectra of $H$. pylori strain UNSW P10 cells (about $10^{8} \mathrm{ml}^{-1}$ ) incubated with $30 \mathrm{~mm}-\mathrm{D}-[\mathrm{U}-$ ${ }^{13} \mathrm{C}$ )glucose at $37^{\circ} \mathrm{C}$. Cells were suspended in sterile liquid semi-defined media of Isosensitest broth. The resonances corresponding to the substrate are shown in the bottom spectrum, and those corresponding to products $\mathrm{C}_{1}, \mathrm{C}_{2}$, and $\mathrm{C}_{3}$ are indicated on the top spectrum. The time at which each spectrum was acquired is shown on the right-hand side. Chemical shifts are given in p.p.m. frequency units (see Methods).

glucose in liquid cultures (Table 1). In the redistribution of the label from substrate to products, between $50 \%$ and $80 \%$ of the ${ }^{13} \mathrm{C}$ labelled nuclei became unobservable (Fig. 2). Little product accumulation was observed during the initial phase, the appearance of resonances arising from catabolic products occurred during the second phase. The rates of substrate disappearance measured using ${ }^{13} \mathrm{C}$ NMR spectroscopy depended on the position of the label on the glucose molecule. The levels using $\mathrm{D}-\left[1-{ }^{13} \mathrm{C}\right]$ glucose declined almost twice as fast as with $\mathrm{D}-\left[6{ }^{13} \mathrm{C}\right] g$ lucose during both phases (Table 1). Catabolic products were also observed in incubations with $\mathrm{D}-\left[1-{ }^{13} \mathrm{C}\right] \mathrm{glucose}$.

\section{Identification of glucose catabolic products}

Three groups of resonances $\mathrm{C}_{1}, \mathrm{C}_{2}$ and $\mathrm{C}_{3}$ were observed to accumulate as a result of glucose catabolism during the second phase (Fig. 2). The spectral position of $\mathrm{C}_{1}$ at 182.99 p.p.m., and the lack of proton couplings observed in proton-coupled ${ }^{13} \mathrm{C}$ spectra indicated that these peaks arose from quaternary carbon atoms. A $J_{\mathrm{CC}}$ coupling constant of $55.19 \mathrm{~Hz}$ for the $\mathrm{C}_{1}$ doublet (Fig. 2) was consistent with coupling to bonded carbon nuclei. The $\mathrm{C}_{2}$ resonances also showed carbon-carbon couplings $J_{\mathrm{CC}^{\prime}}$ of 54.77 and $55.48 \mathrm{~Hz}$ suggesting couplings to two bonded carbon nuclei. The proton couplings of the $\mathrm{C}_{2}$ peaks in proton-coupled spectra were consistent with those of 
Table 1. Apparent rates of $\left[{ }^{13} \mathrm{C}\right]$ glucose utilization during the initial and secondary phases for three strains of Helicobacter pylori

Cells were grown on horse blood agar or horse blood agar supplemented with 30 mM-D-glucose and inoculated into Isosensitest broth medium containing $10 \mathrm{~mm}-\mathrm{D}-\left[6-{ }^{13} \mathrm{C}\right] \mathrm{glucose}$ or $\mathrm{D}-[1-$ $\left.{ }^{13} \mathrm{C}\right]$ glucose.

\begin{tabular}{|c|c|c|c|c|}
\hline \multirow[b]{2}{*}{ Strain } & \multicolumn{2}{|c|}{$\begin{array}{l}\text { Cells grown on } \\
\text { unsupplemented medium }\end{array}$} & \multicolumn{2}{|c|}{$\begin{array}{l}\text { Cells grown on glucose } \\
\text { supplemented medium }\end{array}$} \\
\hline & $\begin{array}{l}\text { Initial phase } \\
{[\mathrm{mmol} \mathrm{min}}\end{array}$ & $\begin{array}{l}\text { Second phase } \\
\left.(\mathrm{g} \text { protein })^{-1}\right]\end{array}$ & $\begin{array}{l}\text { Initial phase } \\
{[\mathrm{mmol} \mathrm{min}}\end{array}$ & $\begin{array}{l}\text { Second phase } \\
\left.\text { protein })^{-1}\right]\end{array}$ \\
\hline NCTC $11639^{*}$ & $8.67 \times 10^{-5}$ & $1.22 \times 10^{-3}$ & $1.14 \times 10^{-4}$ & $5 \cdot 33 \times 10^{-3}$ \\
\hline NCTC $11639 \dagger$ & $15.20 \times 10^{-5}$ & $2.29 \times 10^{-3}$ & ND & ND \\
\hline UNSW P10* & $3.94 \times 10^{-5}$ & $3 \cdot 18 \times 10^{-3}$ & $1.08 \times 10^{-4}$ & $6.50 \times 10^{-3}$ \\
\hline UNSW $921006^{*}$ & $2.36 \times 10^{-5}$ & $0.97 \times 10^{-3}$ & $0.31 \times 10^{-4}$ & $1.26 \times 10^{-3}$ \\
\hline
\end{tabular}

ND, Not done.

${ }^{*} \mathrm{D}-\left[6-{ }^{13} \mathrm{C}\right] \mathrm{glucose}$.

$\dagger \mathrm{D}-\left[1-{ }^{13} \mathrm{C}\right]$ glucose.

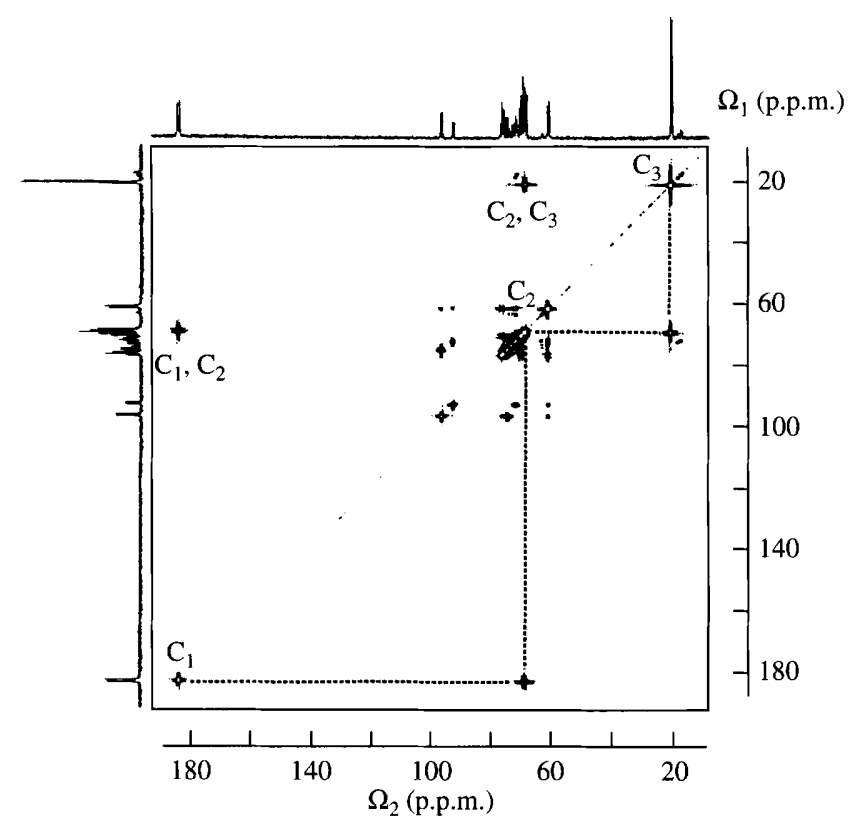

Fig. 3. Two-dimensional ${ }^{13} \mathrm{C}$ heteronuclear correlated (COSYX) symmetrized contour plot of ultrafiltrates from $40 \mathrm{~h}$ incubations of $H$. pylori cells in Isosensitest broth with $30 \mathrm{~mm}-\mathrm{D}-\left[\mathrm{U}-{ }^{13} \mathrm{C}\right]$ glucose. The peaks corresponding to the three carbon atoms $C_{1}, C_{2}$ and $C_{3}$ of the principal product are indicated on the diagonal; the cross-peaks between them are labelled $\mathrm{C}_{1}, \mathrm{C}_{2}$ and $\mathrm{C}_{2}, \mathrm{C}_{3}$. The connectivities between these resonances are indicated by dashed lines. $\Omega_{1}$ and $\Omega_{2}$ are the frequency domains corresponding to the Fourier transformations of the evolution and acquisition time domains, respectively. The onedimensional ${ }^{13} \mathrm{C}$ spectrum is shown on the left-hand side and on the top. Chemical shifts are given in p.p.m. frequency units (see Methods).

methine groups. At $125.77 \mathrm{MHz}$ it was possible to distinguish two doublets at 21.079 and 20.974 p.p.m. in the $\mathrm{C}_{3}$ resonances, with $J_{\mathrm{CC}}$ of 36.78 and $38.31 \mathrm{~Hz}$, and different intensities. Proton-coupled spectra showed different coupling patterns for each of these doublets; the larger doublet at 21.079 p.p.m. was split into two doublets with $J_{\mathrm{CH}}$ coupling constant of $127.81 \mathrm{~Hz}$, this splitting pattern was consistent with that of equivalent methyl protons. The same $J_{\mathrm{CH}}$ coupling constant was measured for the doublet at 20.974 p.p.m. but the splitting pattern was consistent with a methyl group with only two equivalent protons. The connectivities between these resonances observed in the ${ }^{13} \mathrm{C}$ heteronuclear contour plot (Fig. 3) of the ultrafiltrate of incubation products indicated that they arose from the same molecule. The chemical shifts of the peaks were consistent with those of lactate, and not with other possible catabolic products such as propionate or alanine. The two different methyl groups would arise from L-lactate and D-lactate.

Further evidence for the assignments of $\mathrm{C}_{1}, \mathrm{C}_{2}$ and $\mathrm{C}_{3}$ was obtained using ${ }^{1} \mathrm{H}$ NMR spectroscopy. The $\left[{ }^{13} \mathrm{C}-{ }^{1} \mathrm{H}\right]$ map of Fig. 4 shows a correlation of the ${ }^{13} \mathrm{C}$ spectrum with the ${ }^{1} \mathrm{H}$ NMR spectrum of incubation products. The chemical shifts of the proton resonances that correlated with $\mathrm{C}_{2}$ and $\mathrm{C}_{3}$ were consistent with those of the methine and methyl moieties of lactate at 4.147 and 1.358 p.p.m., respectively. Finally, the ${ }^{1} \mathrm{H}$ homonuclear correlation contour plot showed that these resonances arose from the same molecule (Fig. 5), thus confirming the identification of lactate.

\section{Discussion}

The transport of $\mathrm{D}-\left[{ }^{14} \mathrm{C}\right]$ glucose into cells and the appearance of labelled metabolic products in experiments employing $\mathrm{D}-\left[{ }^{13} \mathrm{C}\right]$ glucose as substrate, showed the ability of $H$. pylori to utilize this monosaccharide specifically. Incorporation of labelled carbon atoms into the cellular mass additionally indicated that glucose is transformed into some of the precursors for biosynthesis. 


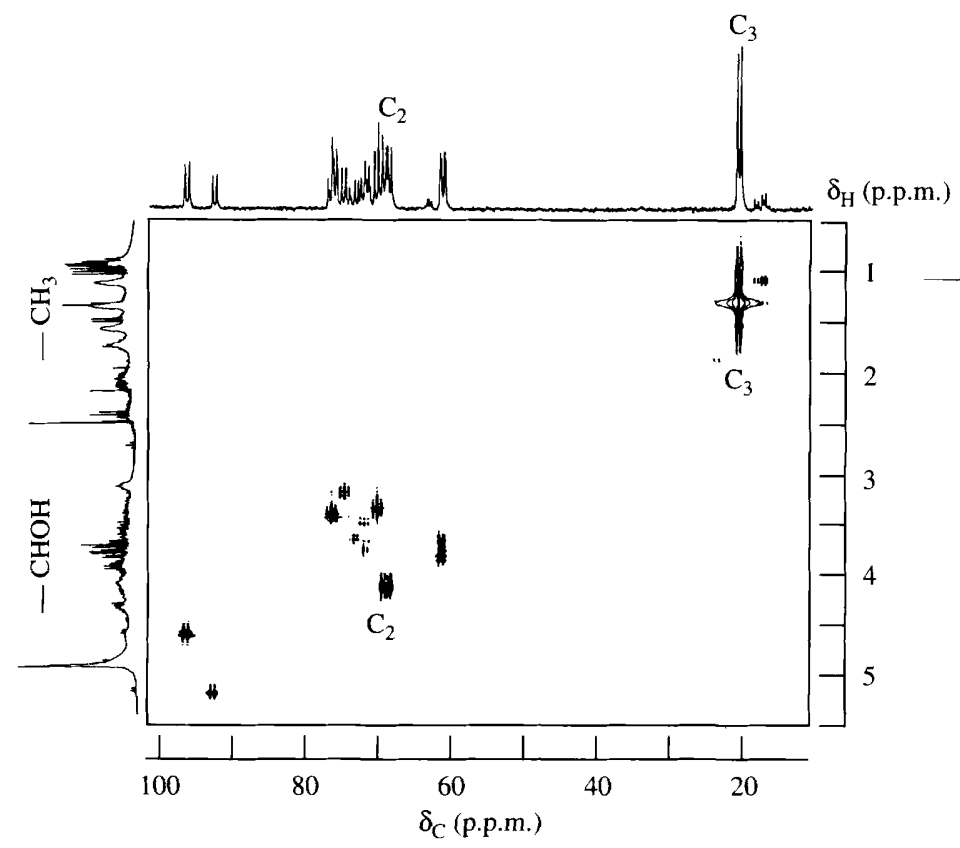

Fig. 4

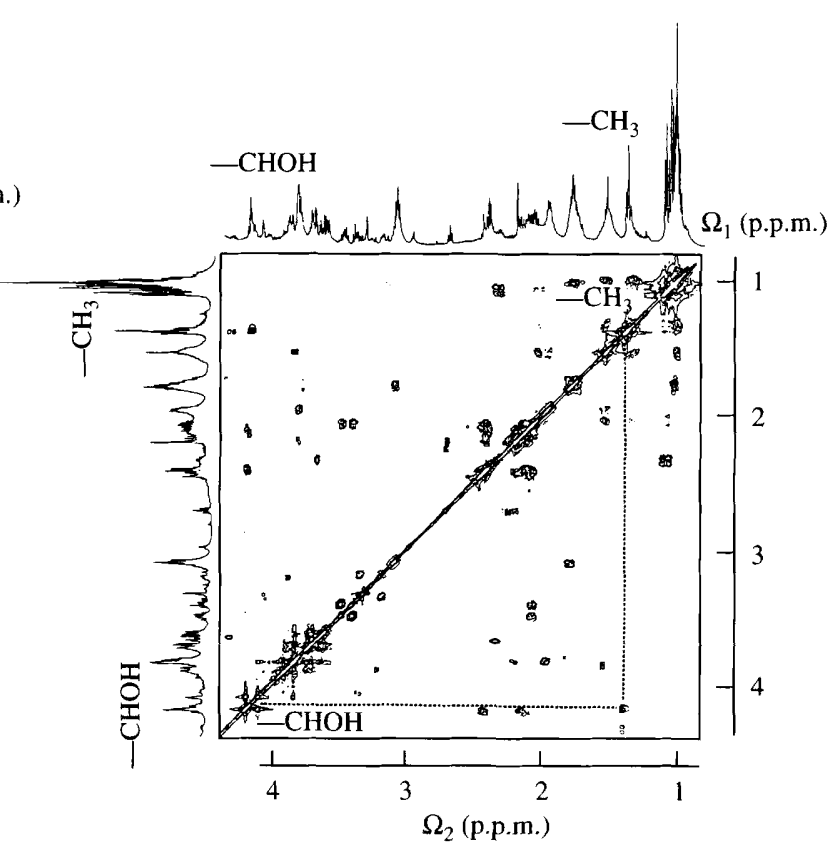

Fig. 5

Fig. 4. Aliphatic region of the two-dimensional $\left[{ }^{13} \mathrm{C}-{ }^{1} \mathrm{H}\right]$ shift correlated map of ultrafiltrates from incubations of $H$. pylori cells in Isosensitest broth with $30 \mathrm{mM}-\mathrm{D}-\left[\mathrm{U}-{ }^{13} \mathrm{C}\right.$ lglucose. The corresponding one-dimensional ${ }^{1} \mathrm{H}$ (left-hand side) and ${ }^{13} \mathrm{C}$ (top) spectra are also shown. $\delta_{\mathrm{C}}$ is the chemical shift of the carbon resonances along $\Omega_{2}$, and $\delta_{\mathrm{H}}$ is the chemical shift of the proton resonances along $\Omega_{1}$. The $\mathrm{C}_{2}$ and $\mathrm{C}_{3}$ resonances are indicated on the map and the one-dimensional ${ }^{13} \mathrm{C}$ spectrum; the corresponding proton resonances are indicated by their respective chemical groups $-\mathrm{CHOH}$ and $-\mathrm{CH}_{3}$. Chemical shifts are given in p.p.m. frequency units (see Methods).

Fig. 5. Two-dimensional ' $\mathrm{H}$ homonuclear correlated (COSY) symmetrized contour plot of ultrafiltrates from incubations of $H$. pylori cells in Isosensitest broth with $30 \mathrm{mM}-\mathrm{D}-\left[\mathrm{U}-{ }^{13} \mathrm{C}\right] \mathrm{glucose}$. The peaks corresponding to the proton resonances of the chemical groups $-\mathrm{CHOH}$ and $-\mathrm{CH}_{3}$ of the principal product are indicated on the diagonal. The connectivity between these resonances is indicated by dashed lines. The one-dimensional ${ }^{1} \mathrm{H}$ spectrum is shown on the left-hand side and on the top. Chemical shifts are given in p.p.m. frequency units (see Methods).

The net loss of ${ }^{13} \mathrm{C}$ label from glucose added to cells can be explained by the incorporation of glucose carbon atoms into macromolecules and cellular structures leading to a decrease in the mobility of these atoms. This would also partly account for the loss of visibility of ${ }^{13} \mathrm{C}$ nuclei in high resolution NMR spectra. Furthermore, the label at the carbon atom in position 1 of glucose will be lost to $\mathrm{CO}_{2}$ in the oxidative phase of the pentose phosphate pathway. The net disappearance of label together with the knowledge that $H$. pylori possesses glucokinase activity (Mendz \& Hazell, 1993) and enzymes of the pentose phosphate pathway (Mendz \& Hazell, 1991), suggested that this pathway participates in the utilization of glucose. This conclusion was supported by the observation that the rates of loss of label measured using $\left[1-{ }^{13} \mathrm{C}\right]$ glucose were approximately twice those using $\left[6-{ }^{13} \mathrm{C}\right]$ glucose (Table 1), reflecting the possible loss of the ${ }^{13} \mathrm{C}$ label in $\mathrm{CO}_{2}$. The identification of lactate as the principal metabolic product that accumulates under the conditions of these experiments, and the appearance of labelled products in incubations with $\left[1-{ }^{13} \mathrm{C}\right]$ glucose indicated that, besides the pentose phosphate pathway, there is at least one other pathway involved in glucose metabolism in $H$. pylori.

Glucose utilization via the pentose phosphate pathway would suggest that, besides being used as a source of carbon for the biosynthesis of macromolecules, its metabolism is also related to the bioenergetic balance of the bacterium. The rate of incorporation of $\left[{ }^{14} \mathrm{C}\right] \mathrm{glucose}$ carbon into cells was constant (Fig. 1); however loss of label from $\left[{ }^{13} \mathrm{C}\right] \mathrm{glucose}$ showed a biphasic pattern (Table 1) suggesting that the micro-organism is capable of adapting to the effective use of this saccharide as an energy substrate, although $H$. pylori can grow in the absence of glucose. This important conclusion is supported by the observation that lactate accumulated only during the second phase. The design of chemotherapeutic agents targeted against specific biochemical pathways of H. pylori must take into consideration the adaptability of the bacterium to obtain some of its energy requirements and biosynthetic precursors from D-glucose, an abundant substrate in its human host. 
This work was made possible by the support of the National Health and Medical Research Council of Australia.

\section{References}

Bock, K. \& Thørgersen, H. (1982). Nuclear magnetic resonance spectroscopy in the study of mono- and oligosaccharides. Annual Reports on NMR Spectroscopy 13, 1-57.

Ferrero, R. L., Hazell, S. L. \& LeE, A. (1988). The urease enzymes of Campylobacter pylori and a related bacterium. Journal of Medical Microbiology 27, 33-40.

Gero, A. M., Scott, H. V., O'Sullivan, W. J. \& Christopherson, R. I. (1989). Antimalarial action of nitrobenzylthioinosine in combination with purine nucleoside antimetabolites. Molecular and Biochemical Parasitology 34, 87-98.

GutTERIDGE, W. E. \& GarboraK, M. (1979). A re-examination of purine and pyrimidine synthesis in the three main forms of Trypanosoma cruzi. International Journal of Biochemistry 10, 415-422.

Hazell, S. L. (1992). The role of Helicobacter pylori urease. A contentious issue. European Journal of Gastroenterology Hepatology 4 (Suppl. 1), S55-S59.

Hazell, S. L., Evans, D. J. \& Graham, D. Y. (1991). Helicobacter pylori catalase. Journal of General Microbiology 137, 57-61.
Hornick, R. B. (1987). Peptic ulcer disease: a bacterial infection? New England Journal of Medicine 316, 1598-1600.

McNulty, C. A. \& DeNT, J.C. (1987). Rapid identification of Campylobacter pylori (C. pyloridis) by preformed enzymes. Journal of Clinical Microbiology 25, 1683-1686.

MARSHALl, B. J. \& WARREN, J. R. (1984). Unidentified curved bacilli in the stomach of patients with gastric and peptic ulceration. Lancet $\mathbf{i}$, 1311-1315.

Mendz, G. L. \& Hazell, S. L. (1991). Evidence for a pentose phosphate pathway in Helicobacter pylori. FEMS Microbiology Letters 84, 331-336.

Mendz, G. L. \& Hazell, S. L. (1993). Glucose phosphorylation in Helicobacter pylori. Archives of Biochemistry and Biophysics 300, $522-525$.

MoRris, A. \& Nicholson, G. (1987). Ingestion of Campylobacter pyloridis causes gastritis and raised fasting gastric $\mathrm{pH}$. American Journal of Gastroenterology 82, 192-199.

Nomura, A., Stemmermann, G. N., Chyou, P. H., Kato, I., PerezPerez, G. I. \& Blaser, M. J. (1991). Helicobacter pylori infection and gastric carcinoma among Japanese Americans in Hawaii. New England Journal of Medicine 325, 1132-1136.

Parsonnet, J., Friedman, G. D., Vandersteen, D. P., Chang, Y., Vogelman, J. H., Orentreicht, N. \& Sibbley, R. K. (1991). Helicobacter pylori infection and the risk of gastric carcinoma. New England Journal of Medicine 325, 1127-1131. 